\title{
Distinctive and Unique Outreach Programs: Promoting Academic Excellence and Diversity
}

\section{Ms. Paula Ann Monaco, Texas Tech University}

Paula is a first year Civil Engineering Ph.D. student and graduate of the Master of Environmental Engineering program at Texas Tech University. Her research interests include water and wastewater treatment, focusing on non-selective advanced oxidation processes for small scale water treatment facilities. Paula participates in outreach programs to help recruit female and URMs to STEM related careers.

\section{Dr. Audra N. Morse, Texas Tech University}

Dr. Audra Morse, P.E., is the Associate Dean for Undergraduate Studies in the Whitacre College of Engineering and a Professor in the Department of Civil and Environmental Engineering at Texas Tech University. She leads the Engineering Opportunities Center which provides retention, placement and academic support services to WCOE students. 


\section{Distinctive and Unique Outreach Programs: Promoting Academic Excellence and Diversity}

\section{$\underline{\text { Abstract }}$}

Participation of K-12 students in outreach programs helps stimulate interest in science, technology, engineering and math (STEM) related fields. These programs introduce underrepresented students to a collegiate experience and dispel myths and fears about higher education. One way to promote these experiences for students is participation in hands-on classes through summer camps. Such classes expose females and historically underrepresented minority (URMs) students to the background theory covering design and applications of environmental engineering. Texas Tech University organizes three residential camps to introduce visiting students to STEM topics specifically; Science It's a Girl Thing (SIGT), Shake Hands with Your Future (SHWYF) and Brazil session of SHWYF. Three distinct groups of students participated in summer classes: international students from Brazil, female students only, and regional students of which the population were females, URMs and traditional white males. Camp participants were surveyed to evaluate the relationship between student attitudes, performance, and recruitment into the environmental engineering field. Campers participated in group and class discussions to present their findings after performing the following exercises: design, construction, and testing of water filter, landfill and oil clean-up scenarios. The classes highlighted the inter-disciplinary nature of the field through the aforementioned hands-on exercises. Students that participated in group discussions and asked questions showed better comprehension and interest in the course based on survey results. Verbal surveys were administered prior to introduction of educational content for evaluation of students' prior knowledge. After both the lesson and hands-on activity, students completed worksheets and participated in class discussions. These written and oral surveys were a means to evaluate the impact of the activities on student learning and recruitment to environmental engineering. The surveys indicated that the students in the female only classes had a better understanding of the material compared to females participating in the mixed gender class. International and traditional students shared comparable background knowledge and performed similarly throughout the activities. International students used drawings and other means of communicating designs showing comprehension of the material in lieu of a language barrier. The summer outreach program spiked international students interest in STEM related fields and enrolling in United States universities to pursue higher education. Common results observed from surveying the three groups were that the students were better able to connect theory and design principles to application after performing hands-on activities. It was observed that students became inspired and encouraged after planning, designing, constructing and testing an engineered solution during various activities. 


\section{$\underline{\text { Introduction }}$}

Interactive STEM summer programs provide visiting students an academic experience at a university campus to dispel common fears and myths about higher education. Outreach programs recruit students to pursue a post - secondary education and increase knowledge about the requirements for entering a four-year institution of higher learning. These outreach programs introduce students to unique experiences and promote academic diversity.

Residential summer camps uniquely bring international and underrepresented minorities (Females, Hispanics and African Americans) the opportunity to participate in mini-courses conducted in a judgment free environment ${ }^{1}$. The courses offered at summer camps introduce students to in-depth knowledge of engineering concepts, design, data collection and analysis through lessons and hands-on activities to connect theory to design. Courses educate students on mathematics, engineering concepts and real-world environmental engineering applications. The students are encouraged to follow the engineers design process of identifying the problem, brainstorming different designs, planning, creating, testing, analyzing or evaluating and improving each design while working through technical hands-on activities. Lessons are structured to educate students and expand general background knowledge to increase activity performance.

These summer camps are great outreach programs helping to recruit students into STEM related fields and increase the enrollment of engineering schools. Outreach programs introduce the younger generation to STEM related fields and spike their interest in problem solving careers. Innovative outreach programs look to reverse the trend of declining enrollment in engineering programs by stimulating younger generation's interest ${ }^{2}$.

Investigation of how students understand the concept of engineering highlight that the various disciplines of engineering are not well known by the younger generation ${ }^{3}$. Outreach programs help close the gap of misconception that all disciplines of engineering means you can fix plumbing or electronic devices. Programs can help educate younger generations that engineers practice in a vast amount of disciplines such as civil, chemical, computer and electrical, environmental, industrial, mechanical and petroleum. Mini-courses to focus on one subdiscipline of engineering can dispel the misconception that engineering disciplines all focus on the same technology and practice ${ }^{3}$.

Texas Tech University (TTU) hosts summer residential camps to immerse students into the university lifestyle where they participate in mini-courses and have access to university amenities such as dormitories, dining halls and recreational centers. Students are provided the unique experience of fully participating in activities simulating the university lifestyle.

Depending on the camp structure, students are exposed to diversity of staff and classmates while educated about the interdisciplinary configuration of higher education. Texas Tech's camp structure and environmental engineering curriculum is detailed in subsequent sections. 
Pre and post-assessment measures were administered for qualitative analysis of student comprehension of the material $^{4,5}$. Prior to each lesson, verbal surveys were performed for each topic. Students were asked basic comprehension questions by the instructor to better understand their background knowledge of engineering concepts. Introduction questions assessed student's comprehension of mathematics, chemistry, and environmental engineering sub-topics of water, wastewater, waste, and air pollution management. Student responses were recorded and compiled to highlight knowledge gaps. Education assessment data can be utilized in growing the effectiveness of the program. Qualitative data allows for a better understanding of the instructors effectiveness as well as the effectiveness of the course. Assessment techniques were used in determining the effectiveness of summer camp outreach programs on spiking females, international and URMs interest in pursuing STEM related studies at the university level ${ }^{6,7,8}$.

The environmental engineering mini-course served three overreaching goals: (1) increase the number of females pursuing engineering; (2) recruit academically strong international students to engineering programs, specifically to TTU; and (3) increase the number of Hispanics, African Americans and other underrepresented minorities (URMs) enrolling in engineering programs. This paper details outreach activities to educate students about engineering and spike their interest in higher education by encouraging the students to ask questions, hypothesize and test their knowledge.

\section{$\underline{\text { Residential Camp Structure }}$}

TTU hosts residential camps during the summer for a variety of age groups to attend summer science classes and participate in hands-on activities. Three camps were offered to the students throughout the summer; Science is a Girl Thing (SIGT), Shake Hands with your Future (SHWYF), and Brazil session of SHWYF ${ }^{9,10}$. Table 1 indicates the participants during the summer sessions along with the number of females, URMs, and Brazilian students enrolled.

SIGT is comprised of only female campers who attended three day sessions of hands-on science classes with a total of 12 hours spent in the mini-courses such as environmental engineering. Sessions were divided into three groups, girls entering grades $5-6^{\text {th }}, 7-8^{\text {th }}$ and $9-11^{\text {th }}$. The programs goals are to provide girls with strong role models, spark interest in science, dispel myths and misconceptions about science and careers in science, and to introduce underrepresented girls to a collegiate experience.

SHWYF allows students of all ethnic and gender backgrounds to explore different fields of study through hands-on opportunities. The goal of the program is to develop student interest and focus on an academic path. Academically talented students, male and female, participate in morning and afternoon classes for four days dedicating a total of 12 hours for each mini-course held during the program. SHWYF offers two sessions for students entering grades $8-11^{\text {th }}$ and $4-7^{\text {th }}$. TTU provides a high school outreach program in Brazil comprised of a full-English curriculum, consisting of American high school courses such as literature, writing, history, economics, 
government and public speaking ${ }^{10}$. As the program expands, students travel to the United States for a three week summer experience that includes enrollment in mini-courses administered by the SHWYF program. Brazilian students range from grades $9^{\text {th }}-12^{\text {th }}$ with a majority being first time visitors to the United States.

Table 1: Number of students attending each camp session divided by grade levels, gender and ethnicity

\begin{tabular}{|c|c|c|c|c|c|c|c|c|c|}
\hline Camp & $\begin{array}{c}\text { Grade } \\
\text { Level }\end{array}$ & $\begin{array}{c}\text { Total } \\
\text { Enrolled }\end{array}$ & Male & Female & White & Hispanic & $\begin{array}{c}\text { African } \\
\text { American }\end{array}$ & Brazilian & Other \\
\hline SHWYF 1 & 8th-11th & 12 & 7 & 5 & 6 & 6 & 0 & 0 & 0 \\
\hline SHWYF 2 & 4th-7th & 8 & 5 & 3 & 6 & 1 & 1 & 0 & 0 \\
\hline SIGT 1 & 5th-6th & 14 & 0 & 14 & 5 & 9 & 0 & 0 & 0 \\
\hline SIGT 2 & 7th-11th & 7 & 0 & 7 & 4 & 2 & 1 & 0 & 0 \\
\hline Brazil & 9th-12th & 40 & 30 & 10 & 0 & 0 & 0 & 39 & 1 \\
\hline
\end{tabular}

\section{Environmental Engineering Course Curriculum}

The overreaching goal of the mini-course was to introduce traditional, URMs and international students to the interdisciplinary field of environmental engineering and conduct daily lessons that cover sub-topics of air pollution control, water/wastewater treatment, solid and hazardous waste management and remediation. Each summer camp session allowed for twelve total classroom hours dedicated to both lessons and hands-on activities. The lessons were broken down into four sub-topics with one activity for each to inform students of current environmental engineering projects. For hands-on activities student were divided into groups of 2-3 people depending on class size. In addition to the primary instructor, two graduate students helped conduct hands-on activities.

The environmental engineering course curriculum has evolved over the past 5 years. A syllabus (Table 2) for the environmental engineering mini-course was developed for students to understand the expectations of the course. Learning objectives were set for each topic covered throughout the course paired with expected outcomes. Learning objectives and expected outcomes were applied to all age groups. The difficulty of design calculations and number of discussion questions increased for high school aged campers. The older students were asked thought provoking discussion questions following activities for deeper understanding of material and to make additional conclusions about engineering applications. Subsequent sections in this paper will discuss the various assessment methods. Hands-on activities were selected to demonstrate current topics and technologies utilized as part of engineered solutions within the environmental engineering field. 
Table 2: Environmental engineering course syllabus listing lesson topics, learning objectives and expected outcomes of the outreach summer camps

\begin{tabular}{|c|c|c|c|}
\hline Lesson & Topic & Learning Objectives & Expected Outcomes \\
\hline \multirow[t]{5}{*}{$\begin{array}{l}\text { Day } 1 \text { - Water } \\
\text { Treatment }\end{array}$} & \multirow[t]{5}{*}{ Filtration } & $\begin{array}{l}\text { Students explain the impact of clean water } \\
\text { on a global level. }\end{array}$ & $\begin{array}{l}\text { Students will evaluate } \\
\text { operation of a water filter } \\
\text { they design. }\end{array}$ \\
\hline & & $\begin{array}{l}\text { Understand the reason for the } \\
\text { infrastructure crisis in the U.S. }\end{array}$ & \multirow{4}{*}{$\begin{array}{l}\text { Students will evaluate } \\
\text { operation efficiency of } \\
\text { different filters. }\end{array}$} \\
\hline & & $\begin{array}{l}\text { Students will compare filtration media } \\
\text { materials and sizes used. }\end{array}$ & \\
\hline & & $\begin{array}{l}\text { Students will estimate removal efficiency } \\
\text { as a function of particle size. }\end{array}$ & \\
\hline & & $\begin{array}{l}\text { Students will calculate overflow rate and } \\
\text { filter surface. }\end{array}$ & \\
\hline \multirow[t]{7}{*}{$\begin{array}{l}\text { Day } 2 \text { - Solid } \\
\text { Waste } \\
\text { Management }\end{array}$} & $\begin{array}{l}\text { Solid } \\
\text { Generation } \\
\text { Rates }\end{array}$ & $\begin{array}{l}\text { Students will compare waste generation } \\
\text { rates to national averages. }\end{array}$ & $\begin{array}{l}\text { Categorizing and } \\
\text { calculating solid waste } \\
\text { generation rates. }\end{array}$ \\
\hline & \multirow[t]{2}{*}{$\begin{array}{l}\text { Waste } \\
\text { Minimization }\end{array}$} & $\begin{array}{l}\text { Students will propose techniques for waste } \\
\text { minimization. }\end{array}$ & \multirow{2}{*}{$\begin{array}{l}\text { Students will recalculate } \\
\text { waste generation rates after } \\
\text { recycling and reusing } \\
\text { wastes. }\end{array}$} \\
\hline & & $\begin{array}{l}\text { Students will compare and contrast } \\
\text { recycling and reuse. }\end{array}$ & \\
\hline & $\begin{array}{l}\text { Solid Waste } \\
\text { Reuse } \\
\text { Strategies }\end{array}$ & $\begin{array}{l}\text { Students will propose ways to reuse solid } \\
\text { waste. }\end{array}$ & $\begin{array}{l}\text { Students will present } \\
\text { brainstorming results to the } \\
\text { group. }\end{array}$ \\
\hline & \multirow[t]{3}{*}{$\begin{array}{l}\text { Waste } \\
\text { Disposal }\end{array}$} & $\begin{array}{l}\text { Students will propose new disposal } \\
\text { techniques. }\end{array}$ & \multirow{3}{*}{$\begin{array}{l}\text { Students will build and test } \\
\text { their landfills and present } \\
\text { results to the class. }\end{array}$} \\
\hline & & Students will design and build a landfill $^{\mathrm{I}}$. & \\
\hline & & $\begin{array}{l}\text { Students will explain environmental issues } \\
\text { of citing a landfill. }\end{array}$ & \\
\hline \multirow[t]{3}{*}{$\begin{array}{l}\text { Day } 3 \text { - } \\
\text { Remediation }\end{array}$} & \multirow[t]{3}{*}{$\begin{array}{l}\text { Oil Spill } \\
\text { Clean Up }\end{array}$} & $\begin{array}{l}\text { Students will discuss the impact of oil } \\
\text { industry on the environment. }\end{array}$ & $\begin{array}{l}\text { Students will present their } \\
\text { findings of which sorbents } \\
\text { used were most efficient. }\end{array}$ \\
\hline & & $\begin{array}{l}\text { Students will propose techniques for } \\
\text { removal of large amounts of oil in the } \\
\text { oceans and subsurface. }\end{array}$ & \multirow{2}{*}{$\begin{array}{l}\text { Students will discuss what } \\
\text { properties contributed to a } \\
\text { certain sorbent being } \\
\text { successful or not. }\end{array}$} \\
\hline & & $\begin{array}{l}\text { Students will evaluate properties of } \\
\text { sorbents and its application when } \\
\text { remediating large oil spills. }\end{array}$ & \\
\hline \multirow{3}{*}{$\begin{array}{l}\text { Day } 4 \text { - Air } \\
\text { Pollution } \\
\text { Control }\end{array}$} & \multirow[t]{3}{*}{ Air Pollutants } & $\begin{array}{l}\text { Students will discuss the impact of air } \\
\text { pollutants on the environment. }\end{array}$ & \multirow{3}{*}{$\begin{array}{l}\text { Students will present } \\
\text { brainstorming results to the } \\
\text { class. }\end{array}$} \\
\hline & & $\begin{array}{l}\text { Students will discuss and propose air } \\
\text { pollution control techniques. }\end{array}$ & \\
\hline & & $\begin{array}{l}\text { Students will discuss how everyday } \\
\text { activities add to air pollution. }\end{array}$ & \\
\hline
\end{tabular}




\section{A. Water filter}

The instructor provided basic knowledge needed for selecting a filter type. The various media and loadings were discussed with the students. Water filters were to be designed using limited supplies that could be easily accessed following a natural disaster. The filter apparatus was constructed using recyclable materials: two liter soda bottle, coffee filters and cotton. The filter media selection included a variety of gravel sizes, sand and other recyclable materials such as plastic pieces, tires, etc. The water filters were tested and evaluated for both removal of suspended solids and discharge flow. The students used a mathematical equation learned during the lesson to calculate their designed filters discharge. The design objective given to the students was to design and construct a filter that used minimal materials, quickly treated the water and removed suspended solids. High school aged students were given an additional task of classifying the filters based on loading rate calculations performed.

\section{B. Waste Management and Landfill Design}

Solid and hazardous waste is a specialized topic environmental engineers manage. The activity began with students separating residential waste into common categories to weigh. A base weight of the waste was determined prior to any management tactics being applied. The students then explored various minimization methods to reduce the amount of waste sent for traditional disposal in landfills. Plastic, cardboard, rubber and paper were separated for recycling and the students then reweighed the waste to be sent to the landfill. The sorting activity allowed students to calculate the specific density of waste and quantify the impact minimization techniques have on waste management. Further calculations translated the data so students could compare the initial volume of waste sent to landfills versus the saved volume of waste sent following minimization methods.

Students determined that waste could be minimized but there is still a portion that will be designated for landfills. Students were taught that landfills are engineered designs for waste disposal and not a hole in the ground known as "dumps". The introductory lesson detailed the lining, waste compaction, gas collection, leachate system and a daily and final cover necessary for entrapment of solid waste. The adapted activity ${ }^{11}$ tasked students with a budget to design, build and test a landfill that is cost effective for large amounts of waste. The landfills were tested with simulated flood, wind and earthquake events. Students were able to collaborate within their group to plan and design the optimal landfill design. Clay was used as both a liner for the bottom and top of the landfill. Plastic strips were used to represent engineered synthetic material such as geomembrane used to construct the bottom liner. Plastic straws were used by the students to represent either an internal leachate system or gas collection system depending on the students design. Additional materials such as sand, gravel and toothpicks were available for students to use at their discretion when designing the optimal landfill. Waste was 
represented by cotton balls soaked in water and food coloring. The capacity of the landfills was determined by the amount of cotton balls ("waste") the landfill could hold. Failure of the designed landfill was determined if colored liquid escaped the structure and contaminated surrounding soil.

\section{Oil spill remediation}

The environmental remediation topic covered oil spills in the ocean which is a current topic in the Gulf of Mexico. Introductory lessons taught students about various clean-up technologies currently used by environmental engineers to manage ocean oil spills. Booming through use of absorbents, skimming, dispersants and biodegradation were technologies discussed and then addressed through a hands-on activity ${ }^{12}$. Within an aluminum pan a natural environment was simulated using gravel representing land, a feather representing wildlife and water. Vegetable oil was introduced to the environment and the negative impacts to wildlife and environment were simulated to emphasize the importance of remediation. The environmental engineers' role was then illustrated by attempting to remediate or clean-up the synthetically made oil-spill. Skimming was attempted using a plastic spoon to physically remove oil from the simulated environment. Booming was tested by placing felt material on the impacted areas of the environment. Finally, dispersants were tested using dish soap to represent chemical applications of remediating a site.

Three technologies were introduced to the students allowing them to brainstorm and plan remediation techniques using some or all of the technologies available to them given a problem statement. A second activity was performed for the students to better understand optimal properties of sorbents when using booming technology to manage oil spills. Students created four mock oil slicks in individual cups to test a variety of materials; cotton balls, sponges, paper towels and Styrofoam. Supplies were chosen to represent both natural and synthetic materials. Materials were placed in the oil for five minutes allowing for sorption to occur. Thickness of the oil slick was measured before and after placement of each material. The total volume was then calculated for each material allowing students to draw conclusions about ideal sorption properties from what was observed and taught during the lesson.

\section{Course Assessment}

Course surveys can be used as an assessment tool in engineering education for evaluating student knowledge and attitude about engineering. Surveys also measure student confidence in their academic abilities ${ }^{13}$. Verbal surveys were conducted prior to each lesson asking students about their knowledge of engineering related topics, specifically environmental engineering. These surveys asked general questions allowing the instructor to understand the baseline of knowledge 
the students would expand during the summer camp activities. Survey questions used for assessment of student education included:

- What is engineering?

- What core classes taken in high school would you associate with engineering?

- Name engineering jobs.

- What is environmental engineering?

- What are sub-topics of environmental engineering?

- Name environmental engineering roles.

- Were the activities helpful with connecting theory to design? How so?

- Were lessons relevant to current issues in your community?

- Has this course influenced you to pursue STEM related majors through higher education?

Post course assessments included group discussions, activity worksheets, verbal surveys and class participation. Students were asked questions following each activity that allowed them to draw overreaching conclusions about the lessons taught. Activity worksheets allowed students to develop independent conclusions tying theory taught during the lesson to design during hands-on activities. Group discussion would follow to introduce students to collaboration with peers and improvement of individual designs. These techniques assessed the environmental engineering curriculum, hands-on activities, knowledge of the sub-topics taught and students interest in pursuing STEM related fields of study at universities.

\section{Course Assessment Results}

Students stated through verbal surveys the lessons were kept to manageable lengths and provided the background knowledge needed for them to complete the assigned hands-on activities. Students agreed lessons were concise, diverse in topic and relative to students' background and current issues. Participants confirmed the activities encouraged positive interactions between students allowing them to develop collaboration and communication skills while stimulating their interest in discussed topics. The activities provided identifiable results allowing students to connect theory taught during lessons to practice. The instructor observed that through hands-on activities the participants became self-confidant, engaged, stimulated and accomplished by developing, designing and testing engineering solutions. Assessments were made using a combination of group discussion responses, students participating vocally and answers to survey questions. From verbal survey results the instructor concluded that students had a better understanding of STEM related fields and that the program provided a clear picture of engineering applications following completion of the mini-course. Residential camps also provided students a better understanding of what to expect from four-year universities. About $65 \%$ of the students expressed interests in pursuing STEM related majors through postassessment survey and discussion. From the students that expressed interest in STEM related majors $25 \%$ were female, $28 \%$ URMs and the rest were traditional students. Finally, students 
exhibited a greater comprehension of the environmental engineering field and interdisciplinary topics through the detailed group discussions and conclusions drawn on individual student activity worksheets.

Using the comprehensive results of surveys and worksheets qualitative performance observations of female, international, URMs and traditional students were made.

Female Students: During SHWYF, female student's participation was minimal and subdue. During group discussions and verbal surveys females were not interactive and showed disinterest in the course. Activity worksheet results indicated to the instructor that female students understood the material by detailed responses written but were not comfortable sharing their findings based on female participation during group discussions. It was observed during SHWYF the presence of male students introduced an intimidation factor that stifled female student participation and compression of engineering concepts. SIGT removed the intimidation factor for female students which increased verbal survey responses, activity participation and confidence in presenting designs. SIGT continues the encouragement of females to pursue STEM related careers and provides a positive environment to expand their education. Worksheets of students enrolled in the female only session exhibited increased performance observed by the completeness and creative solutions recorded.

International students: Brazilian students participating in the program are considered academically strong and are enrolled in an English high school curriculum. Students stated that the environmental engineering course was selected to expand their education and understanding of international issues. Brazil shares similar technologies and engineering design concepts with the United States providing Brazilian students with base knowledge parallel to regional students. The instructor observed that activities encouraged critical thinking and ingenuity from participants through worksheet responses and talking to students during group discussions. Conclusions were made throughout the course: there was language disconnection when using brand names and common terminology; students used alternate methods of describing and presenting ideas and designs such as diagrams and drawings when verbal communication became difficult; and the Brazilian student course performance and comprehension of material was similar to regional students. When polled, 18 out of 40 Brazilian students expressed interest in attending universities in the United States for higher education with 14 considering STEM related majors.

URM Students: SHWYF had female and male Hispanic and African American students enrolled who stated at the completion of the course they were interested in pursuing higher education. It was observed that these students were not aware of the STEM related opportunities and were not able to distinguish between engineers, computer science or other technology based fields. Through the lessons and activities the students broadened their horizons and stated through surveys outreach programs have stimulated their interest in pursuing higher education. Observations were concluded from group verbal surveys and individual activity discussion 
sheets. The structure of the hands-on summer course provided guidance and encouragement for students to pursue higher education by simulating an atmosphere that spiked student interest in learning. The environmental engineering curriculum exhibits hands-on activities to attract K-12 students to the engineering field that historically do not pursue higher education.

\section{$\underline{\text { Conclusion }}$}

Female students gained confidence in their designs and were more inclined to share their results in an environment where intimidation from the presence of male students was removed. International and traditional students shared comparable background knowledge and performed similarly throughout the activities. The paired lessons and hand-on activities provided students with knowledge while keeping them involved and stimulated throughout the course. The mixture of teaching techniques, lessons and hands-on activities, promoted critical thinking and introduced students to the collaborative nature of engineer design through group work. Students left the course with increased comprehension and interest in STEM related fields specifically environmental engineering as determined from exit surveys. The environmental engineering course was able to spike the interest and educate females, URMs and international students about the opportunities available to them. The instructor concluded from verbal surveys that there was an increased interest in pursuing STEM related majors at universities. Students from Brazil stated there was an increased interest in STEM related fields and attending United States universities after visiting the campus and completing the course. Activities increased student confidence allowing them to ask questions and advice about pursuing academic excellence at the university level. The diverse nature of the residential summer camps activities will help accomplish the final goal of increasing future URMs enrollment in engineering programs.

For future summer camp outreach programs there should be implementation of systematic evaluation tools to gain telling results of how the program improves throughout the years ${ }^{13}$. The next step is to gather quantitative data for better understanding of the impact the activities and curriculum have on the students. Verbal surveys could be expanded to written pre and postsurveys with ranking values to better obtain data. Feedback would allow the instructor to reevaluate the emphasis of each course topic to ensure ample time is provided to the students for better comprehension of the material. 


\section{$\underline{\text { References }}$}

1. Yilmaz, M., Ren, J., Custer, S., \& Coleman, J. (2010). Hands-On Summer Camp to Attract K-12 Students to Engineering Fields. IEEE Transactions On Education, 53(1), 144-151.

2. Davis, C. E., Yeary, M. B., \& Sluss, J. r. (2012). Reversing the Trend of Engineering Enrollment Declines with Innovative Outreach, Recruiting, and Retention Programs. IEEE Transactions On Education, 55(2), 157-163.

3. Montfort, D., Brown, S., \& Whritenour, V. (2013). Secondary Students' Conceptual Understanding of Engineering as a Field. Journal of Pre-College Engineering Education, 3(2), 1-12.

4. Bogue, B., Shanahan, B., Marra, R. M., \& Cady, E. T. (2013). Outcomes-Based Assessment: Driving Outreach Program Effectiveness. Leadership \& Management In Engineering, 13(1), $27-34$. doi:10.1061/(ASCE)LM.1943-5630.0000209.

5. Nilson, L. B. (2010). Teaching at its best: A research-based resource for college instructors, Third Edition. San Francisco, CA US: Jossey-Bass.

6. Milgram, D (2011). How to Recruit Women and Girls to the Science, Technology, Engineering, and Math (STEM) Classroom. Technology \& Engineering Teach. 71(3), 4-11.

7. Moskal, B., \& Skokan, C. (2011). Supporting the K-12 Classroom through University Outreach. Journal Of Higher Education Outreach And Engagement, 15(1), 53-75.

8. Slovacek, S. P., Whittinghill, J. C., Tucker, S., Rath, K. A., Peterfreund, A. R., Kuehn, G. D., \& Reinke, Y. G. (2011). Minority Students Severely Underrepresented in Science, Technology Engineering and Math. Journal Of STEM Education: Innovations And Research, 12(1-2), 5-16.

9. "IDEAL Summer Camps - The Institute for the Development and Enrichment of Advanced Learners." Texas Tech University. (2013). [Online]. http://www.depts.ttu.edu/diversity/ideal/ camps_programs.php.

10. Smith, B., Edwards, C. (2013). TTUISD: The Remarkable Expansion of Its Program in Brazil. The Journal of Higher Education at TTU. 5(3).

11. Parks, J., Carlson, D. W. (2013). Hands-on Activity: Design, Build and Test Your Own Landfill. Contributed by: Integrated Teaching and Learning Program, College of Engineering, University of Colorado at Boulder. [Online]. http://www.teachengineering.org/view_activity. php?url= collection/cub _/activities/cub_enveng/cub_enveng_lesson05_activity2.xml.

12. Perez-Suarez, S. D., Straten, M., Schaefer Zarske, M., Yowll, J. (2013). Hands-on Activity: Oil Spill Cleanup. Contributed by: Integrated Teaching and Learning Program, College of Engineering, University of Colorado at Boulder. [Online] http://www.teachengineering.org/view_activity.php?url=collection/cub _/activities/cub_enveng/cub_enveng_lesson01_activity1.xml.

13. Hilpert, J. J., Stump, G. G., Husman, J. J., \& Wonsik, K. (2008). An exploratory factor analysis of the Pittsburgh freshman engineering attitudes survey. 